\title{
THE MULTINATIONAL CORPORATION IN THE ENLARGED EUROPEAN COMMUNITY
}

\author{
BrIAN D. Forrow*
}

I

\section{Defining the Multinational Corporation}

To deal constructively with the role of the multinational corporation as affected by the enlarged European Community, one should have a fairly clear idea of just what is meant by a "multinational corporation." There is, however, no general consensus on a working definition of this much-used and poorly understood term. ${ }^{1}$

What is a multinational corporation? Wondrous creatures come to mind, such as the unicorn - the mythical animal with the body and head of a horse, the hind quarters of a stag, the tail of a lion, and a single horn in the middle of the forehead. Another is the hippogriff. Betty Bock, the Conference Board's director of antitrust research, tells us that a hippogriff is part horse and part griffin, and a griffin is part eagle and part lion. ${ }^{2}$ If a hippogriff is a symbol for a domestic conglomerate, my own imagination falters before the challenging search for a symbol for the multinational corporation which may also be a conglomerate.

A multinational corporation may be (and has been) defined as a corporation holding substantial foreign investment but with a predominant home base; or a corporation with sales abroad about equal to domestic sales; or a corporation that has lost its national identity through wide international ownership. ${ }^{3}$

Yet another definition rejects the notion' that what is to be defined is the "multinational corporation"; the relevant term is held to be the "multinational enter-

- Vice President and General Counsel, Allied Chemical Corporation. Many friends and associates have been most generous and helpful in the preparation of material for this paper. However, although I am sure they would agree with many of my conclusions, neither they nor Allied Chemical bear any responsibility for this expression of them.

${ }^{1}$ After some research in this field one can fully appreciate the truth of the remark by then President's Assistant for International Economic Affairs (now Secretary of Commerce), Peter Peterson, that "[t]here has been a tendency to say more than is known about these new and extraordinarily important cnterprises." I P. Peterson, The Untred States in the Changing Worid Econoniy iii (U.S. President's Council on Internat'l Economic Policy, GPO I97r) [hereinafter cited as Peterson Study]. An cxecutive of a well-known pharmaceutical concern has been quoted as saying that the multinational corporation "... has something in common with happiness or misery. No one can define it, but you always know when it is there." Antonio Knoppers, a senior executive of Merck \& $C_{0}$., as cited in Teague, Multinational Corporations: Profiles and Prospects, The Conference Bonro Record, Sept., 197x, at 20.

${ }^{2}$ Bock, The Conglomerate and the Hippogriff, The Conference Bonrd Record, Feb., 1972, at 6, I5.

${ }^{8}$ Teague, supra note I, at 20, citing Mr. Knoppers, as the source. This breakdown was given by Mr. Knoppers in his testimony at the Hearings on a Foreign Economic Policy for the 1970 's Before the Subcomm. on Foreign Economic Policy of the Joint Economic Comm., 9Ist Cong., 2d Sess., pt. 3, at 685-99 (1970). See also S. Rolfe, The Multinationax Corporation 8 (Foreign Policy Ass'n, Headlino Series No. I99, 1970). Rolfe cites IBM, Shell, and Unilever as examples of "the few firms that have evolved as far as the transnational stage." $I d$. The Rolfe pamphlet is an excellent short overview of the multinational enterprise phenomenon and includes a supplementary bibliography. 
prise," which is then defined as "a cluster of corporations of diverse nationality joined together by ties of common ownership and responsive to a common management strategy." It would seem that there is a good deal of sense in the use of the term "enterprise," with its transnational implications, to embrace the whole animal, and to reserve the use of the term "corporation" for the constituent parts with their varying national identities. Such an approach puts into sharper focus the areas of accord and disaccord between the multinational enterprise and the politicaleconomic interests of the nation-states of the world. It is precisely in this areawhere the multinational enterprise begins to regard itself, consciously or uniconsciously, as at least in part a supranational enterprise-that tensions build and reactions by nation-states, harmful to the multinational enterprise and often harmful to the best interests of the nation-states themselves, take place. As expressed by Professor Vernon, "[N]ation-states have come to give credence to some of the more uninhibited projections of the future which picture the multinational enterprise as the overwhelmingly dominant vehicle of the world's business." Professor Vernon predicts a "painful and complex" process of accommodation, one in' which the multinational enterprise may have to learn to live with a measure of control coordinated among sovereign states and to abandon its customary position that if the enterprise is a "good citizen" of each country in which its subunits function', the enterprise has fulfilled its public duty. ${ }^{6}$

Returning to the definitional problem per se, Norman Macrae, the deputy editor of The Economist, has a "special regard" (although, one would imagine, a regard tempered with the same tongue-in-cheek that Sir Arnold must have employed in advancing the definition) for the definition' attributed to Sir Arnold Hall of Hawker Siddeley: "A multinational corporation is an American-registered company manufacturing its products where labor is cheapest, and channelling its profits to another country where taxation is lowest or preferably non-existent." If this definition (with which much of organized labor in the United States seemingly would agree in light of the support given to the Hartke-Burke Bill examined later in this paper) is to be taken seriously, it seems as wrong-headed as it purports to be hard-headed. The reference to "American-registered," as a necessary element of

\footnotetext{
- Vernon, Economic Sovereignty at Bay, 47 Forergn AfFairs Iro, Ir4 (Ig68).

"Id. at Ix6. For some examples of the type of "uninhibited projections" which Professor Vernon evidently had in mind consider the following statement of N. R. Danielian, President of the International Economic Policy Association (as quoted in Teague, supra note $I$, at 23-24): "There is no other instrumentality with the same flexibility, inventiveness, initiative and effectiveness as the multinational corporation .... No armies, no governments, no foreign aid, no international institutions can match this achievement." Or the prediction of Professor Perlmutter of the Wharton School of Finance, University of Pennsylvania, that in the 1980's a global industrial system will emerge with "stateless worldwide firms" and with nation-states actually fostering "boundary-leaping combines" for the sake of taxes, jobs, and economic growth. U.S. NEwS \& WORLD REPORT, July I9, I97x, at 38, 4I.

'Vernon, supra note 4, at I22. See also U.S. Comm'N ON INTERnational. Trade aNd INvestMent Policy, United States INTERnational Economic Policy IN AN INTERdependent Worid Ig0-93 (I97I) (Report to the President) [hereinafter-cited as Wilinas CoMmission REPorT]; Vagts, The Multinational Enterprise: $A$ New Challenge for Transnational Law, 83 HaRv. L. Rev. 739, 745 (1970).

${ }^{7}$ Macrae, The Future of International Business, THE EconOMrs, Jan. 22, 1972, at-v, xxv.
} 
the definition; alone betrays an insularity and a narrowness of view which ignores the fact that the multinational enterprise is not now and, in fact, has never been an exclusively American phenomenon. ${ }^{8}$ The growing rate of investment by non-United States multinationals in the United States itself is a factor that tends to be forgotten. ${ }^{9}$

To land on a broad, working definition, the term "multinational corporation" probably best covers any enterprise which operates producing units in three or more countries. $^{10}$

But such a working definition adds little to our understanding of the complexities of the subject. To penetrate these complexities, one must examine in some depth the rapidly growing literature. There has been a fantastic rushing into print on the subject in the last few years by various study groups. ${ }^{11}$

The Economist did a lengthy survey on the future of international business which appeared in' the January 22, 1972, issue. These are some of the observations:

The biggest business development of the past two decades has been the growth of giant multinational corporations. This is a phenomenon which has the great advantage for a journalist that nobody can give accurate figures about it, because everybody has a slightly different definition of what a multinational corporation is. But by boldness in definition, crudeness in extrapolation, and shamelessness in purloining from the best American or British scholars on the subject ... my assumption here is that the total production of goods and services by foreign subsidiaries of large firms working outside their parent companies' countries now amounts to over $\$ 300$ billion a year. You can put the figure up to $\$ 450$ billion a year by laxness

\footnotetext{
${ }^{8}$ See S. Rolfe, supra note 3, at I4-I5, 20, 34 for interesting data on non-U.S based multinational enterprises.

- To cite just a few recent examples: On Thursday, April 6, r972, the Wall Street Jottrnal reported that more than half the southern states have sent representatives to Munich to talk over investment possibilities with scores of European concerns. In the last seven years, South Carolina has attracted $\$ 725$ million in forcign spending on plants, particularly in textile-related industries. South Carolina claims that it has more West German capital than any place in the world outside of West Germany. In Spartanburg, South Carolina, alone there are eight German-owned plants. Wall St. J., Apr. 6, x972, at $x$, col. 5 .

The following day, the Wall Street Journal had a lead article entitled A TwaWay Ocean. The article centered on investment by Brown Boveri \& Co., a Swiss electrical equipment maker, which is investing \$ro million in new servicing facilities in Richmond and is actively considering the possibility of building turbine generators in the United States. Wall St. J., Apr. 7, I972, at I, col. 6.

Approximately fifty-seven percent of AKZONA Inc., better known as American Enka, one of this country's leading fiber producers, which is based in Asheville, North Carolina, is owned by a Dutch company, AKZO, which happens also to be in the chemical business.

${ }^{10}$ John $\mathrm{H}$. Dunning, Professor of Economics, University of Reading, Hearings on a Foreign Economic Policy, supra note 3 , at 794 .

${ }^{11}$ See, e.g., I \& 2 Petzrson STUdy; the research study by Professor Robert B. Stobough and his associates at the Harvard Business School, U.S. MULTINATIONAL ENTERPRISE AND THE U.S. EcONOMY (1972); the study by the Office of International Investment, Bureau of International Commerce, U.S. Department of Commerce, The Multinational Corporation-Studies on U.S. Foreign Investment (1972); Commattee for Economic Development, The United States and the European Community: Polictes for a Changing Wordd Economy (I97r). For an interesting and more specifically "legal" treatment of the problems posed by the multinational enterprise, particularly in relation to nation-states, and their possible resolution, see Vagts, supra note 6.
} 
in definition and a bit of double counting, or down below $\$ 200$ billion by using the definition favored by debunkers. ${ }^{12}$

The Economist further suggests that there are 300 multinational corporate giants: I87 American industrial companies, one-third as many European and Japanese firms and then about 50 big multinational banks and insurance groups which tend to be left out of too many calculations. ${ }^{13}$ If one takes the roo largest economic units in the world, only 50 of them are nations and the other $5^{\circ}$ are the largest of these 300 multinational companies. ${ }^{14}$

II

\section{American Labor and the Multinational Corporation}

There is nothing new about multinational corporations. One of the first, of course, was the English East India Company. But we have at least one early American candidate: the Singer Company built its first overseas factory in Glasgow in I867. Recently, the AFL-CIO and other labor unions have been carrying on as if they had indeed discovered something new and use the term "multinational corporation" in a highly pejorative sense. They strenuously urge the adoption of some severely restrictive legislation known as the Hartke-Burke Bill. ${ }^{15}$ Deputy Secretary of the Treasury Charls Walker told a group of chemical manufacturers not long ago that this bill is "the worst piece of proposed legislation to come down in the history of the Republic."16

The principal reason that the concern voiced by the labor unions with respect to multinational corporations is shared by many others is undoubtedly the r971 trade deficit, the first deficit since 1893 , amounting to over two billion dollars. As a country we must face the facts and we must recognize that the days of huge United States trade surpluses are probably gone forever. The Conference Board's twenty year projection for the U.S. economy is that the merchandise trade surplus will disappear permanently by the mid-rg8o's. ${ }^{17}$

The second major reason that the union attack is receiving wide support is the domestic unemployment rate of about 6 per cent. The trade deficit and the unemployment rate are both due in large measure to alarming domestic inflation. This inflation has become such a preoccupation that it has caused a drastic reversal of philosophy and policy by a Republican President in the form of peacetime wage-price controls and a devaluation of the dollar. As many US. business and other leaders

\footnotetext{
${ }^{12}$ Macrae, supra note 7 , at xxi.

${ }^{13}$ Id. See also Vagts, supra note 6, at 750, for a slightly different breakdown based on the 500 largest corporations in the world.

${ }^{14}$ Macrae, supra note 7 , at xxi.

${ }^{15}$ S. 2592, 92d Cong., Ist Sess. (r97I); H. 8784, 92d Cong., Ist Sess. (I97I).

${ }^{16}$ Address before a Chemical Forum meeting, Manufacturing Chemists Association, Washington, D.C., Mar. 6, 1972.

${ }^{17}$ THE U.S. Economy IN I9902, prepared by the Conference Board for The White House Conference on the Industrial World Ahead: A Look at Business in 1990 (I972) at 22. This trend continues to be borne out in the trade component of our balance of payments for 1972 to date.
} 
have pointed out, the problems we experienced in this country from 1966 through I97I were unique. Some may disagree, but it is my personal conviction that they were largely caused by our ill-advised military venture in Vietnam and by the equally ill-advised way in which this activity was financed.

Faced with the trade deficit and continuing unemployment in a period of inflation, the AFL-CIO has departed from its traditional free-trade position and is trying to pin the ribbon of blame on American multinational enterprise for America's loss of competitive position. This is an appealing approach for the unions to take, particularly in an election year, because they have more votes and voters than the corporations on which they propose to pin the ribbons. They say that the multinational corporations are setting up facilities abroad that result in exporting jobs, exporting technology, and importing products from foreign subsidiaries into the United States, and that the answer is to impose severely restrictive quotas, do away with the foreign tax credit, and intensify our regulation of international capital transactions.

Briefly summarized below are some of the features of the Hartke-Burke Bill:

(I) Quotas would be authorized on all imports on a category-by-category and country-by-country basis. The quotas would be based on the average annual quanity of each category produced in each country and imported during the years 1965 to I969. A further downward adjustment would be made if U.S. production in the category falls off.

(2) Income of foreign subsidiaries would be subject to U.S. income taxes when earned, whether or not repatriated.

(3) The foreign tax credit would be repealed.

(4) The President would be authorized to prohibit any direct or indirect transfer of capital abroad when he determines that employment in the U.S. would be decreased by the transfer.

(5) The President would also be authorized to prohibit any U.S. patent holder from producing a patented product abroad or from licensing someone else to produce it abroad.

There are other provisions-some substantive, such as country of origin labeling requirements, some more or less procedural, such as the vesting in a new Foreign Trade and Investment Commission, made up of representatives from labor, business, and the general public, of certain functions now performed by other government departments-but the above listing sets forth the principal features.

We all have to recognize that we Americans and our Government have been somewhat carried away by notions of unrestricted free trade, and, unfortunately, in many instances we have, on the one hand, encouraged our competitors to export to this country and, on the other, permitted our trading partners to continue restrictions which prevent American companies from penetrating their markets. Japan is a classic example. But the new textile agreement with Japan, although not far-reaching enough to satisfy our domestic textile producers, does go a long way toward meeting our problems in that particular area; and there is reason to believe 
that a bilateral or multilateral approach can be at least as effective with respect to other products so that our domestic producers will not be met with unfair competition from abroad. Something more than the General Agreement on Tariffs and Trade is clearly required.

There is also no doubt that labor is honestly concerned with the effect of the operations of multinational corporations on the U.S. economy as a whole and the U.S. job picture in particular. In statements on the subject labor spokesmen talk about the necessity of dealing with "the real world" which they describe as "a far cry from the never-never land of the text books"18 and of the need for "practical solutions."19 Labor complains that

Multinational firms and banks, often U.S.-based, now juggle global operations for maximum tax and income benefit from the laws of each host nation. Their global management decision-making and transactions are intra-corporate and frequently reach beyond the law of any single nation. ${ }^{20}$

How much of this indictment has perhaps been brought on the heads of multinational enterprises by their occasional "supranational" posturing and dream of freedom from "political restraint" is a question already adverted to. ${ }^{21}$

However, it is a serious mistake to think that if companies are discouraged from investing abroad, they will be able to supply the same markets from plants within the United States, thereby increasing domestic production and employment. Recent studies suggest that the effect of blocking investments by U.S. multinational companies in foreign manufacturing plants would simply be to cause them to lose their share of the foreign market to local industry or to other non-United States multinational companies.2 Also of interest is a Department of Commerce Study, which contains some compelling facts which meet head-on some of the assumptions contrary to fact which are still being made with respect to U.S. multinational corporations. ${ }^{23}$ The facts show that instead of contributing to domestic unemployment and increased import competition, American multinational corporations by their activities abroad are generating markets for United States exports and helping

\footnotetext{
${ }^{18}$ Jager, Foreign Trade and Investment Act of 1972, Colum. J. WorLd Business, Mar., 1972, at i6.

${ }^{10}$ Minority Statement of Commissioners I. W. Abel, President of the United Steelworkers of America, and Floyd E. Smith, International President, International Association of Machinists and Aerospace Workers, published as Annex 2 to the Williams Commisston Report, supra note 6, at 338 .

${ }^{20} \mathrm{Id}$. at 340.

${ }^{21}$ See notes $5 \& 6$ stipra and accompanying text.

22 See, e.g., Stobough Study, supra note II.

${ }^{23}$ U.S. Department of Commerce Study, supra note II, particularly $\$ 3$, Trends in Direct Investment Abroad by U.S. Multinational Corporations 1960-1970. According to this study, of $\$ 8.7$ billion total earnings on U.S. direct investment abroad in 1970 , \$7.9 billion was repatriated, a plus of considerable proportions in our balance of payments figures. Of $\$ 59.7$ billion in sales by foreign affiliates of multinational enterprises, only $\$ 4.7$ billion was exported to the United States (of which approximately half can be attributed to imports of Canadian-made transportation equipment under the 1965 U.S.-Canadian Auto Agreement) as against $\$ 42$ billion sold locally and $\$ 8.7$ billion exported to third countries.
} 
domestic employment in the long run. The study also shows that foreign investment has a favorable impact on' the balance of payments. ${ }^{24}$

The Conference Board study, The U.S. Economy in 1990, indicates that the merchandise trade deficits projected for 1985 and 1990 will be more than offset by surpluses on non-merchandise transactions. These reflect largely the anticipated sharp growth in the return on U.S. overseas investments as the United States increasingly comes to assume the characteristics of a "mature creditor" country.

\section{III}

\section{Effects of the Entarged European Community on American Business}

What is the enlarged European Community going to do to American businessmen and American lawyers? Several things, but it is at least doubtful that the effect will be substantially different for the so-called multinational corporation from what it will be for other corporations seeking to penetrate foreign markets.

First of all, there is the prospect for increasing use of the English language. The view that if English is good enough for the Queen of England, it ought to be good enough for anyone, is bound to gain impetus as a result of the entry of the United Kingdom into the European Common Market. ${ }^{26}$ That should save a lot of money and misinterpretation in translations into English. (Then all we will have to do is translate the English into American!)

Secon'd, great progress on international monetary reform is in the offing. There is no need to be seriously disturbed by the devaluation of the dollar, except insofar as it reflects the unfortunate inflation that led to devaluation. In that respect, the psychology of the President's wage-price freeze and Phase II Program is bound to have a constructive effect in slowing down the expectation of contin'uing inflation, although many economists are probably right in saying that inflation was going to be corrected in due course anyway.

Third, there may be beneficial effects on our own exports from the lower average external duty applicable in' the enlarged Common Market compared with the old British tariffs. ${ }^{27}$ But a lot of work needs to be done on non-tariff barriers. In this respect, one can hope that our own Government will more effectively represent the American business community than it has in the past.

Fourth, we may see some improvements in our export trade with Canada and

24 Id. at 5 .

${ }^{25}$ THE U.S. ECONOMY IN I990, supra note $x 7$, at 22.

${ }^{20}$ In this regard The Economist has somewhat smugly commented that "English already seems to be taking over the Brussels corridors-sorry, conloirs-with French retreating into the council chamber like Latin in the Vatican." TrIE Economist, Jan. I, 1972, at Survey 36.

${ }^{27}$ See Williams COMmisston REPORT, stspra note 6, at 204-05, indicating that the European Community's common external tariff (CET) is almost two percentage points lower on the averagc. This study also points out, however, that any such advantage could be more than offset by the deterioration in our competitive position brought about by duty-free trade between Britain and continental markets in sectors where both the British and the continental countries are highly competitive with United States products, such as chemicals, electrical machinery, and transport equipment. Id. 
other countries as a result of adjustments in the British Commonwealth preference system. ${ }^{28}$

Fifth, the European Community has entered into "special trading arrangements" with over 30 countries in the Mediterranean, African, and other areas and is seeking further extension of such arrangements. While these arrangements are defended as part of the Community's broader preferential policies toward developing countries and as essential elements of the over-all development assistance programs of Community member countries, they can be seen as discriminatory measures against U.S. exports. It has been recommended that further extension of these "special arrangements" be discouraged as inconsistent with the most-favored-nation' principle embodied in the GATT, and that elimination or phasing out of existing ones be sought. $^{20}$

But if pressed to characterize the effect on American multinational corporations of the enlarged European Community, one would have to say that the effect is not likely to be very great and that American multinational business leaders probably have not substantially changed their plans for the next ten years to take into account the enlargement. It is interesting to note that the Conference Board projections for the U.S. economy in Iggo do not even mention it.

In summary, the European Community has been in existence for about fifteen years, but whether it has caused any great change in the organization and operation of multinational corporations is doubtful. For example, we have been waiting for years for evidence of a great trend toward mergers within the existing European Community, but relatively few have occurred. The multinational corporations have subsidiaries all over Europe now just as they always have had. American corporations have substantial exports to the European Community just as they had before. And most of us expect that to continue.

To be sure, there may be some readjustments in how the European subsidiaries of American corporations are organized, managed, and operated. The best managed American companies always give most specific answers to the perennial question: "Why do you set up or maintain a subsidiary here?" They consider availability of raw materials, the extent of the market, expectations or achievements of production costs, marketing costs, the advantages or disadvantages of some local product differentiation-all in dollars and cents terms. ${ }^{30}$ Among such adjustments, it seems likely that the management of European subsidiaries of American multinationals will increasingly be European rather than American. It also seems likely that even the top management of American corporations in the U.S. will increasingly

\footnotetext{
${ }^{28}$ Id. at 205. The Committee for Economic Development study, supra note $I x$, at 32, suggests, however, that this advantage could be offset by the export competition in third country markets by those countries (e.g., South Africa, Canada, and Australia) no longer having Commonwealth preferences with Britain. There will also be added pressure for exports from these markets to enter U.S. markets.

${ }^{30}$ Williams Commisston Report, supra note 6, at 205-06, 208-09, 213; Committee for Economic Development study, supra note Ir, at 23, 47 .

30 THE EconosisT, supra note 7 , at Xxv.
} 
be European. Another easy prophecy is that there will be increasing emphasis both in the United States and Europe on timely disclosure of information of interest to investors. Thus, The Economist foresees international regulations about publication of foreign subsidiaries accounts and suggests that the best hope for the multinational firms is that the regulations will be drawn up by responsible bodies like the European Commission. ${ }^{31}$

It might be appropriate to mention a few observations about the role of lawyers for multinational corporations in the enlarged European Community. Until now most of the European Community practice of law has related to antitrust and tax matters. The Continental Can proceedings may contribute to concern in this field, but I think it fair to say that there may have been an over-reaction by many American lawyers to the Community antitrust rules. ${ }^{32}$ On the other hand, one widely experienced counsel for a major British-Dutch multinational corporation recently confided that he was convinced that the reaction of American lawyers had been appropriate and constructive and had forced European leaders to recognize the directions in which some of their more zealous colleagues in Brussels were leading them. We will probably see more and more of the development of larger European law firms-after all, it isn't too long ago that partnerships were most unusual in France. We should also find that the European law firms will be giving more attention in the future to matters involving taxation, antitrust law, securities law, and general corporate practice. Fin'ally, we will see more and more emphasis on the development of strong internal legal departments for multinational corporations in Europe, just as in this country.

It seems clear that the European economic challenge will grow increasingly stronger, whether or not the European Community is enlarged. We Americans already know about the Japanese challenge. As a matter of fact, the booming sale of Japanese automobiles in the United States, right in the front yard of the big producers in Detroit, has demolished a lot of what Mr. Servan-Schreiber told his European readers in his famous book. Les défis are coming from all quarters!

What the enlargement will do, however, if it finally becomes an' unchallenged reality, will be to define "the geographic extent of the nucleus of a new economic, and eventually political, union in Western Europe."33 The enlarged European Community will become an econbmic power with a population larger than the United States and a gross national product approaching ours. To cite just one aspect of

\footnotetext{
${ }^{\mathrm{s1}}$ Id. at xxvi.

${ }^{32} 2$ CCH CoMm. Mrt. Rep. I 948I (197I), Journal officiel des Communautés Européennes, Jan. 8, 1972, at L25.

${ }^{83}$ I Peterson STUdy 23. There has been concern about the political implications of the enlarged Community and the possible supranational activity along socialistic lines. The Economist has pointed out, supra note 7 , p. xxxvi, that public authorities-let alone international public authorities-are proving to be incredibly inefficient producers for the modern age and that this is a principal concern for the future. These are thoughts that give one pause about whether we Americans are correct in stressing, as we always have, the desirability of the ultimate political unification of Europe as a third force to counteract the Russians, and now the Chinese, and to some extent, the Japanese.
} 
the strength of the enlarged Community, it is estimated that it will account for nearly $40 \%$ of world trade as a whole, and approximately $50 \%$ of world trade in industrial products, which would be three times the United States share. ${ }^{34}$ It is true that about half of the European Community trade is amon'g its members, but even ignoring internal trade, the expanded European Community would account for about $25 \%$ of the world's trade or as much as $40 \%$ more trade than does the United States.

Let's consider the European multinational challengers, as contrasted to the challenge, for a moment. A glance at the Fortune list of the 200 largest corporations outside the United States will show that there are fifty companies on the Fortune list of non-United States corporations larger than Allied Chemical Corporation, the author's own company, which is one of the roo largest corporations within the United States. And of the fifty, there are in Europe alone fourteen multinational corporations engaged in the business of selling chemicals with sales or assets in excess of those of Allied Chemical. Furthermore, all of the present Community countries plus Switzerland and the United Kingdom are represented on the list of fourteen. In the chemical business, probably the most formidable is ICI, with annual sales of over $\$ 3.5$ billion. When Allied Chemical talks about competing in the European Community, those are the companies that we have in mind. There are giants on the earth these days-both here and abroad.

These established facts show that today's business climate on the national and the international scene is one of formidable competition-there is a great squeeze on corporate profits. There is at the same time a disturbing lack of appreciation on the part of most people in the U.S., including the labor unions, of the importance of corporate profits to the health of the entire economy.

Where does this competive challenge from formidable European challengers leave us? It leaves both us and our European friends facing pretty clear, though diametrically opposed, options.

The enlarged European Community could become a kind of regional inwardlooking bloc or it could become a groupin'g with open and constructive relationships with the world as a whole. The same choice is now faced by the United States, with an increased sense of urgency in light of the proposed Hartke-Burke Bill. If we attempt to construct an economic fortress in America, our European friends can be expected to construct a fortress of their own in Europe. And then we are all losers.

\section{ConcLusion}

The key word in all of this is "interdependence." One is reminded of a particularly mordant maxim of the Duke de la Rochefoucauld, who lived about three hundred years ago, and the maxim goes like this: "Nous avons tous assez de force

\footnotetext{
"2 2 Peterson Study 7. See also Williams Cominisston Report, supra note 6, at I99-200, 202, 2 II.

${ }^{85} 2$ Peterson Study 7.
} 
pour supporter les maux d'autrui." of us has enough strength to bear up under the ills that befall another." If we are honest with ourselves, we must recognize that this contains an irreducible kernel of truth. Even those of us who are most concerned with the problems of others almost inevitably find that we are able to bear the burden of those problems. But the maxim slides off the point because in an interdependent world, the concerns of others are our concerns, particularly in light of the speed of modern transportation and communication. In other words, can United States labor responsibly take the view in an interdependent world that it can bear up under the ills that might befall American multinational corporations as a result of, for example, artificial trade or investment restrictions? The case studies show that, in the long run, American labor might well suffer as much as business from such restraints.

Perhaps a better maxim for labor to ponder is one from Jean Cocteau: "Puisque ces événements nous dépassent, feignons d'en être les organisateurs." ("Since these events are threatening to overtake us, let's take the position that we started them.")

Multinational corporations and multinational labor organizations have much work to do to nurture a sense of economic and political responsibility. Multinational they may be; supranational, in the sense of freedom from political and economic restraint, they cannot be. To suggest (as has been suggested) that multinational corporations, to remain truly international, may someday be "forced" to emigrate and locate their headquarters in neutral territory will invite the very sort of political suspicion that such corporations are now experiencing, the suspicion that such corporations wish to be "global runaways" from economic, political, and legal responsibility. ${ }^{37}$ This dream of operating out of Tobago without interference from any government is essentially just that-a dream, and a dream not worthy of the dreamer. Judge Ellenborough pointed out 160 years ago that Tobago cannot rule the world. ${ }^{83}$ Nor can any multinational corporation. Nor, so far as I am aware, does any leading multinational really wish to try.

In the words of now Secretary of Commerce Peterson the "real world," which everyone wishes to come to grips with, from labor leaders, through government officials, to multinational business executives and the corporations they manage, is actually a world of "shared leadership, shared responsibility, and shared burdens." 30 The real question is how multinational corporations can best assist in achieving such goals. In order to keep our inflation under control and our industry competitive, we are going to have to give increasing attention to improvements in productivity, and this project will require the assistance and cooperation of management, labor, and government. Eventually the new mobility of people and ideas should lead to a

\footnotetext{
${ }^{36}$ La Rochefoucauld, Oeuvres Complètes (Bibliothèque de la Pléiade I957) REFlexions ov Sentences et Maximes Morries, No. I9, at 409 (5th ed. 1678).

${ }^{\text {a7 }}$ Minority Statement of Messrs. Abel and Smith to Wiltiams Commission Report, supra note Ig.

${ }^{38}$ Buchanan v. Rucker, ro3 Eng. Rep. 546 (K.B. 1808).

39 I PETERson STUDY 50 (emphasis omitted).
} 
fairly equal wage and salary for work of equal skill everywhere-a result greatly to be wished.

The world can well use enlightened multinational business leadership. The view that that government governs best which governs least holds true internationally as well as domestically. One need make no apologies for the free enterprise system or the profit incentive system as the best basis for ensuring economic progress throughout the world.

Wendell Willkie, Chairman of one of the predecessors of the Southern Company, later a senior partner in a Wall Street law firm which bears his name to this day, a Presidential candidate in I940 against Franklin D. Roosevelt and later a special representative for the President on an around-the-world tour in 1942, delivered some thoughts in his book One World ${ }^{40}$ which appear to have particular application here:

Our thinking in the future must be worldwide. ${ }^{41}$

Good will has been stored up for us, like credit in a bank account, by those Americans who pioneered in the opening of new roads, new airways, new shipping lines. Because of them, the peoples of the world think of us as a people who move goods, and ideas, and move them fast. ${ }^{42}$

In nearly every country I went to, there is some great dam or irrigation project, some harbor or factory, which has been built by Americans. People like our works, I found, not only because they help to make life easier and richer, but also because we have shown that American business enterprise does not necessarily lead to attempts at political control. ${ }^{43}$

We are ... now changing completely from a young nation of domestic concerns to an adult nation of international interests and world outlook. ${ }^{44}$

Economic freedom is as important as political freedom. Not only must people have access to what other peoples produce, but their own products must in turn have some chance of reaching men all over the world. There will be no peace, there will be no real development, there will be no economic stability, unless we find the method by which we can begin to break down the unnecessary trade barriers hampering the flow of goods. Obviously, the sudden and uncompromising abolition of tariffs after the war could only result in disaster. But obviously, also, one of the freedoms we are fighting for is freedom to trade. ${ }^{45}$

[T] his world demands the full participation of a self-confident America. ${ }^{46}$

These thoughts were formulated almost thirty years ago. They remain as true today-in the context of multinational enterprise-as they were then.

\footnotetext{
${ }^{\circ 0}$ W. WILLKIE, ONE WORLD (1943).

1 Id. at 2.

${ }^{12}$ Id. at 158 -59.

${ }^{43} I d$.

"Id. at 187 .

"Id. at 204-05.

${ }^{10}$ Id. at 205-06.
} 